\title{
Implementing Pragmatism And John Dewey's Educational Philosophy In Jordanian Public Schools
}

Omar M. Khasawneh, Yarmouk University-Irbid, Jordan \& Al Ain University of Science and Technology, UAE Ruba M. Miqdadi, Yarmouk University-Irbid, Jordan

Abdulhakeem Y. Hijazi, Yarmouk University-Irbid, Jordan

\begin{abstract}
The teachings and writings of John Dewey, an American philosopher and educator, offer insightful influences on contemporary education, not only in the United States but also worldwide. His philosophy of education, commonly referred to as Pragmatism, focused on learning by doing as an alternative to rote knowledge and strict teaching. The purpose of this study is to investigate the extent to which this philosophical thought is implemented in Jordanian public schools according to Jordanian teachers. Both quantitative and qualitative methods were employed in this study. The findings reveal that Jordanian teachers believe Pragmatism is implemented in Jordan to a moderate degree.
\end{abstract}

Keywords: Pragmatism; John Dewey; Educational Philosophy; Public Schools; Jordan

\section{INTRODUCTION}

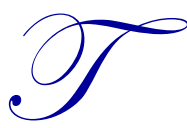

hroughout his life, John Dewey (1859-1952) established a theory of education that required justification and explanation. This theory of learning was connected to a strategy of teaching and, most importantly, his personal philosophy. His philosophy required an understanding of what constitutes a good society and the right way of life, and an acknowledgment that change is a condition of life. He emphasized that the nature of wisdom, understanding, and intelligence is fundamentally moral. Even though he is no longer widely known, Dewey was a writer, professor, theorist, and philosopher whose ideas have had an impact on community and modern education throughout the twentieth century, particularly in the USA. He is mostly recognized and known as the pragmatist educationalist of that century (Field, 2007).

John Dewey, America's most famous philosopher, wrote a great deal because he had an audience who sought his views on people from Plato to Franklin Roosevelt and subjects from immorality to the place of cooking in primary education. After the age of 35 , he shifted his writing from Christianity to secular faith in democracy, social reform and, most importantly, education. In addition, he wrote on subjects such as philosophy, religion, politics, and art. Dewey provided his nation a philosophy through which its citizens may maneuver a more intellectual path in their lives for educational scholastic history (Ryan, 1995).

For Dewey, a democratic society must be mobile and dynamic; it is a society in which teachers know that what works for one student might not work for another. He believed that experience is not a mental state that is within us; instead, we are within experience. For Dewey, a democratic society is not one that makes provisions for equal participation in its good for all its members. This kind of society involves flexible readjustments of its institutions through interactions among the different forms of life (Boisvert, 1988; Campbell, 1995; Gouinlock, 1972; Sleeper, 1987; Welchman, 1995).

Dewey was a curious visionary because he did not speak about long-term goals or cities not built with hands. He was a visionary about the present and the potential of the modern world, modern society, and modern 
man. He became the most influential preacher for liberals, reformers, schools, school teachers, and democrats. He will remain, for the foreseeable future, a rich source of intellectual nourishment for anyone not absolutely locked within the anxieties of their own heart and not absolutely despondent and hapless about the prospects of the modern world (Ryan, 1995).

Boisvert states, "Dewey was a complex thinker who held together many strands that we might no longer think blend particularly well. As we move into the twenty-first century, we must choose which strands to emphasize and which to leave behind" (Boisvert, 1988, p. 161). For him, Dewey's intellectual ancestry challenges the whole notion of thinking in terms of premodern, modern, and postmodern. He adds, "Our quest should be to absorb and update what is best from the past, adjust its misplaced emphasis, eliminate its errors, and incorporate novel elements needed to address our own time" (Boisvert, 1988, p. 157).

Dewey's view on child growth and education is illustrated by a description of his thoughts on children's play and by an excursion to the kindergarten or "sub-primary" department of his laboratory school. Dewey emerges from this debate with a "pre-curricular" view of education for young children and with powerful arguments for continuity between informal and formal education. In this pre-curricular view, education starts with everyday concrete life experiences. These are the "crude beginnings" that will gradually grow into "accomplished results" the more formal subjects and disciplines (Berding, 1999).

Education is a good way of life through which the transmission of culture occurs. People seek new ways to express themselves in natural development and growth. Education is beneficial for individuals who are in need of change, and change is good for people who can direct its course. People need knowledge, intentions, intelligence, and good will to turn this change into their advantage. Progressive education in a democratic society is about change in thoughts, feelings, and internal constraints (Eldridge, 1998; Rockefeller, 1991).

To date, no study has considered the implementation of Pragmatism and the educational philosophical thought of John Dewey in the Jordanian public schools. This study aims to analyze Dewey's philosophical thought as an influential figure throughout the Jordanian public schools from the perspectives of teachers.

\section{Goals of the Current Study}

The purpose of this study is twofold. First, it presents the degree to which Pragmatism, or the philosophical thought of John Dewey, is implemented in Jordan. Second, it investigates whether this degree is influenced by variables such as gender, major, and experience.

\section{The Problem}

At present, it is possible to study Dewey's contributions and it is crucial to revisit his work in order to clarify some misconceptions. In Jordan, the function of Dewey's work has been troubled by some dominant religious beliefs, philosophy, and understandings of education. Recently, there has been concern about Dewey's educational thought in Jordan. His views on education may possibly be very relevant to contemporary questions about schooling and education. Therefore, the problem that this study addresses is the fact that there has been little research on the implementation of John Dewey's educational philosophical thought in Jordanian schools. Accordingly, in order to implement the pragmatic educational approach in the Jordanian educational system, this study provides insight into possible teaching methods in classrooms. These methods provide students with opportunities to take ownership over their learning.

\section{The Significance}

The collection and variety of Dewey's writings and his influence on philosophy, education, political theory, and the social sciences throughout the twentieth century places him alongside other thinkers who became foremost authorities on modern thoughts and ideas. Given the lack of previous studies, the current researchers believe that this new study of Dewey will provide information to educators in Jordan, in particular, and the Middle East region, in general. 
This paper builds valuable bridges between the ideas of John Dewey and Jordanian teachers. On one hand, this paper helps international educators understand the degree to which this pragmatic philosophy is implemented in Jordan. On the other hand, this paper encourages Jordanian teachers to learn more about this philosophy and John Dewey's ideas.

Given the changes in the Middle East and the continuing push from societies to move toward democracy, the researchers believe that these efforts should start at school. John Dewey talked a lot about education, democracy, and the interrelations between these concepts. Therefore, another contribution this paper makes is to invite other researchers to study how Dewey's ideas could help accelerate the process of democratizing schools and education.

\section{RESEARCH QUESTIONS}

This study addresses the following research questions:

1. To what degree do Jordanian public school teachers believe that the philosophy of John Dewey is implemented in Jordanian public schools?

2. Is there any significant statistical difference $(\alpha=0.05)$ between teachers' responses in terms of their gender, major, and teaching experience?

\section{REVIEW OF LITERATURE}

The purpose of this section is to provide a survey of relevant literature on the topic of this study. A great deal of literature worldwide has been written about John Dewey, in general, and his influence in the field of education, in particular. However, no previous study has been reported in the literature, to the best of the authors' knowledge, which examines the implementation of John Dewey's educational philosophical thought in Jordanian public schools from teachers' perspectives. On the other hand, large amounts of literature and research studies are found in the Western world. Thus, for the purpose of this study, this literature review includes earlier studies conducted in the West in addition to a few studies conducted in the Middle East region. The researchers felt that it would be relevant to organize this section into subsections on Dewey's philosophy, in general, his educational philosophical thought, and the intimate relationship between philosophy and education, according to Dewey. In addition, a brief discussion of the Jordanian educational system will also be presented.

\section{Dewey's Philosophy}

Dewey explains that "any person who is open-minded and sensitive to new perceptions, and who has a concentration in connecting them, has, in so far, a philosophic disposition" (Kaminsky, 1992, p. 181). Dewey sought, in his philosophy, to go beyond what he felt were deceptive differences set by other philosophers. By concentrating on experience as well as practice, he overcame the distance between the living being and its milieu to highlight the interface (Eldridge, 1998). The dualistic idea of the soul and world entails a false impression of the tie between knowledge and social happiness, involving individualism and free will, and communal domination and power. The person's mind maneuvers as the instrument of reformation, although the human entity will not be secluded from the world. Man is a purposeful constituent and component of his society, his culture, and his social order (Rayan, 1991).

He discarded the dualistic view of the mind or intellect versus material or the body, claiming that the mind was a result of progression or evolution, not a merge from a superior being. Nonetheless, he kept away from the materialist argument that made thinking look as if it is unplanned and inappropriate. His philosophical teaching is identified as instrumentalism. For him, nature is a continuously flowing stream and thinking is an instrument or tool to escape from a given state, full of vagueness and disagreements, to a novel and better condition because of its new sense and better density (Rayan, 1991; Welchman, 1995; White, 1943).

Dewey contributed two other aspects to Pragmatism - the psychological aspect, along with its biological drift that significantly influenced Pragmatism, and the logical aspect which was transformed into the theory that constructive science is accurate. He asserts that cognition involves creating ideal tools or instruments that can be 
used to cope a given situation, maintaining that the mind is a mechanism for understanding reason. Ideas are teleological weapons of the mind; they are artificial, flexible, and adjustable. They owe their firmness to the vital tasks they serve. Philosophy's duty is no longer to explain truth, morality, and virtue. Rather, it is to visualize as a language activity within which thoughts or ideas are scrutinized for their enriching intellectual history, which shows how values and beliefs come to be reasonable (Diggins, 1991). Diggins writes, "Dewey looked to philosophy to develop a methodology for dealing with an environment of disruptive change" (Diggins, 1991, p. 2).

Pragmatism, Dewey's contribution to the world of philosophy, promised to help people know what to do when facing challenging situations. He supported an instrumental approach to knowledge as Pragmatism promoted insightful intelligence to tolerate society (Diggins, 1991). Some of his major philosophical works are How We Think; Essays in Experimental Logic; Reconstruction in Philosophy; Experience and Nature; The School and Society; Human Nature and Conduct; Logic: The Theory of Inquiry; Ethics; Theory of Valuation; Art as Experience; Studies in Logical Theory; Democracy and Education; and The Quest for Certainty (Hickman, 1990).

Philosophy was defined as a generalized theory of education. It was described as a form of thinking that originates in what is uncertain about the subject matter of experience. It aims to locate the nature of the perplexity or confusion and to frame hypotheses to test in action. In philosophic thinking, the uncertainties that are examined are associated with widespread social conditions and aims, resulting in a conflict of organized interests and institutional claims (Dewey, 1966).

In order to understand Dewey's philosophical thought, we have to understand that "doing philosophy" is symbolic of a collective examination of culture and a way of life. Furthermore, the individual does not need to live as a philosopher to promote the self-corrective strength and the character of investigation; instead, this must be promoted in each member of the learning community (Johnson, 1995; Rorty, 1979). Dewey writes:

...philosophy is an attempt to comprehend; that is, to gather the varied details of the world and of life into a single inclusive whole, which shall either be a unity, or, as in the dualistic systems, shall reduce the plural details to a small number of ultimate principles.... Whenever philosophy has been taken seriously, it has always been assumed that it signified achieving a wisdom which would influence the conduct of life. (Dewey, 1944, p. 324)

\section{Dewey's Educational Philosophical Thought}

As an educator, Dewey is celebrated for his teaching methods using experimental observation (a progressive system in education), and as a philosopher, he is known for the development of Pragmatism. Education transmits culture, and culture generates values and assigns meanings. Dewey, who associates different philosophical aspects with culture and society, had his own views on politics. As Ryan writes, "Dewey's Pragmatism was essentially a peacetime doctrine and credible only in a society that was in most respects harmonious, prosperous, and morally at ease with itself" (Ryan, 1995, p. 157).

Philosophy, as an educational theory, was a type of thinking that emerged from what is uncertain in the subject matter of experience. It aims to trace the nature of the confusion and provide a structure to resolve the confusion. A philosophic thought contains reservations that are created in common societal circumstances and aspirations. Philosophy is an overt formulation of visions and systems through which a stable feeling of happiness may be produced. Education is the process through which these desirable changes would be attained, but it is not simply a theory about what is enviable. Consequently, philosophy could be defined as the "theory of education" and an intentionally accomplished performance (Dewey, 1944).

Even though Dewey was an influential figure in politics, his alliance with progressive education was even more important. He made schools provide extra consideration to themes that capture the essential thoughts of individuals. The modern curriculum, a more practical one than the classical, offers students more realistic information, in contrast to the traditional curriculum that offered important knowledge to students. The modern curriculum made tools available to students that showed them where to go and how to utilize these techniques (Johnson, 1995). 
Dewey argued that it was not enough to reject traditional education nor was it enough for progressive educators to throw out everything the old schools had done. He realized the difficulty of giving an account of the educational experience that would elicit a kind of discipline and an approach to the syllabus and the authority of the teacher in the classroom that would grow out of experience itself. In Democracy and Education, he argued that new education must ask this question: "How were we to acquire the capacity for wider, deeper, more organic experience and the capacity to communicate it?" (Ryan, 1995, p. 282). Intelligent activity reveals the competence of the young person to plan his/her activities and manage his/her doings in the business of the world (Ryan, 1995). The philosophy as education promoted by Dewey liberates us from the strict notion of practice. He talked about what he saw as the indivisible affiliation between philosophy and education (Kaminsky, 1992; Schilpp \& Lewis, 1989).

\section{Boisvert states:}

Experience is a central term in the Deweyan vocabulary. Indeed, it figures prominently in the titles Dewey chose for two of his most important works, experience and Nature, and Art as Experience.... Experiencing is a fully human activity. It can be separated neither from human interests, nor from active experimentation ... experience [is] not to be understood in the empiricist sense of simply receiving impressions. (Boisvert, 1995, pp. 122-124)

Dewey transformed art works into sampling of fine art, moving away from the idea that an artificial cultivation of the wholly independent categories of "art" and "fine arts" do not exhaust human creativity. Making is an ongoing process which includes what the artist fabricates and what the artwork itself prompts as it enters into community experience (Boisvert, 1995).

\section{The Intimate Relationship between Philosophy and Education}

As previously mentioned, philosophy, as an educational theory, was a type of thinking that emerged from what is vague in the subject matter of experience. A philosophic reflection deals with doubts that are treated as general collective situations. Philosophy is an obvious formulation of ideas and methods through which a stable sense of happiness could be formed. Education is a method through which this change would be achieved, although it would not continue to be a theory about what is desirable. Therefore, philosophy may perhaps be defined as a "theory of education" (Dewey, 1944).

The educator and learner are involved in the curriculum concerned with the nature of subject matter. The educator's task is to modify stimuli so that the response will result in the formation of desirable intellectual and emotional dispositions. The educator's attitude towards the subject matter is very different from the learner's attitude towards the subject matter. In other words, the educator already has the knowledge of what is to be taught whereas the learner is in the process of acquiring the same knowledge (Dewey, 1944).

Dewey emphasized the significance of the distinction between play and work. Play and work have the traits of the initial stage of knowledge, including learning how to do things and becoming acquainted with things and processes through performance. When activities are developed and grow more complicated, they gain more meaning by greater attention to the achieved specific results. He states:

It is important not to confuse the psychological distinction between play and work with the economic distinction. Psychologically, the defining characteristic of play is not amusement nor aimless. It is the fact that the aim is thought of as more activity in the same line, without defining continuity of action in reference to result produced. (Dewey, 1944, p. 205)

According to Dewey, the significance of pedagogy, as a theory of education, protects us from the impression that mental conditions are themselves complete things. In addition, it shows that mind and intelligence, or purposeful engagement in a course of action, are identical. This indicates that development and training of the mind presents an atmosphere that stimulates such activity. Second, it protects us from the notion that subject matter is something independent and isolated. Moreover, it shows that the subject matter of learning is identical with all objects, ideas, and principles that are resources or obstacles to the continuous intentional pursuit of a course of action. The developing course of action is the unity that holds together an independent mind and an independent world of objects and facts (Dewey, 1944). 
Dewey also argues that experience comprises a vigorous and inert component. The vigorous component seeks an experiment and the inert component experiences something acting upon it. In education, experience is above all an "active-passive issue not cognitive." Although the evaluation of the value of an experience lies in the perception of its associations or continuities with an educative experience that results in knowledge and understanding, eventually the value of knowledge is substandard to its application in thinking (Dewey, 1944).

Method is a declaration of the manner of a subject matter that is cultivated successfully and productively. It results from the examination of lessons learned from experiences. Methods formulate instruction and learning. The method is derived from studying what really occurs with the goal of improving in on later occasions. The concept of methods secluded from subject matter is related to the artificial notion of the discipline, a concern previously noted. Learning is straight and alert, and it is a result of occupation with a subject matter. Methods of teaching are methods of an action intelligently intended for ends. The qualities of good teaching methods are openness, flexible intellectual interest or an open-minded willingness to learn, integrity of purpose, and acceptance of responsibility for the consequences of one's activity including thought (Dewey, 1944).

In addition to the literature written by and about Dewey, the researchers also referred to two research studies conducted in the Middle East region regarding Dewey's influence on education.

One study was conducted in Jordan on the impact of Pragmatism on Arab education. The researcher concluded that the pragmatic philosophical and educational principles have influenced Arab education in terms of the philosophy of education, methods of instruction, translation, curricula, university educational textbooks, and educational research. Additionally, the study results indicated that Pragmatism weakened the Arab educational system, marginalizing the role of religion within the educational process, and contributing to a separation between Arab society and its educational system (Soraty, 2008).

In sum, through his philosophy, Dewey wanted to go beyond what he felt was the ambiguity argued by other philosophers by concentrating on experience. He linked the living being to its surroundings to underscore their connection. While he thought that most of man's actions were formed by tradition, he alleged that change frequently created circumstances that normal intellectual thoughts could not clarify. The consequential strain led to inspired belief in which man strived to reinstate organization in the unbalanced atmosphere. For him, thought was by no means simply introspection; instead, it was a way man connected to his surroundings. Dewey assumed that worldwide education would prepare people to break through routine into inventive notions. Nevertheless, during the past two decades, research on school change has proposed why several progressives failed to implement Dewey's theory fully (Darling-Hammond \& Sclan, 1996; Fullan, 1991; Goodlad, 1984; Hargreaves, 1997; Lieberman \& Miller, 1999). The final part of this section will present a brief discussion of the Jordanian educational system.

\section{Jordanian Educational System}

The state of Transjordan, which was established in 1921, inherited a traditional educational system from the Ottoman government. It comprised of only some private elementary schools in addition to four public elementary schools located in four major cities. The curricula of those schools contained religious and moral education, plus simple arithmetic. By 1936, many other schools were built in cities as well as in the villages. Science, geometry, history, geography, religious studies, and language arts were added to the school curricula (Jordanian Society for Inheritance Care, 1997).

Educational reform to improve the upbringing of the younger generation was an urgent need to encourage the nation's potential growth. As a result, the government initiated procedures to broaden educational options and improve the curricula content. The new curricula included subjects such as religion, Arabic language, social science, natural science, hygiene, painting, needlework, singing, and some physical training and military training for boys and girls (Khalifeh, 1986). To improve schooling, learning institutions spread throughout the country. As a result, the number of children receiving high-quality education was paramount in the Middle East, and a large number of official private and public schools were established (Randall, 1968). Seale explained that there was ".... drive to develop institutions of higher learning with nearly thirty mostly private community colleges, and - as of December 1981 - two major universities with over 20,000 students and a third one just starting construction" (Seale, 1983, p. 90). 
Since 1939, a series of laws and regulations eradicated the earlier educational laws and providing an outline for the contemporary system. The creation of the Ministry of Education in 1939 led to the creation of sovereign schooling in the kingdom, and its mission was to govern and oversee schools, and build up educational study programs (Patai, 1958; Khalifeh, 1986). During the 1950s, the educational system encountered critical growth with central changes in terms of its objectives, modern philosophy, and enhanced teaching methods because of the amalgamation of the East and West Banks, which introduced profound changes and gave rise to urbanization and industrialization.

In 1955, a major educational progress was the "General Education Law No. 20" whose primary purpose was to grant learning opportunities for all people. This led to "Law No.16, 1964" which derived its philosophy from the constitution and the social, political, economic, and psychological realities of the nation. This was the educational philosophical foundation in Jordan, which the Ministry of Education espoused for approximately 20 years. However, in order to meet twenty-first century challenges, several modifications emerged over the next two decades (Amayreh, 1997; Al-Tal, 1998).

A new educational philosophy emerged between 1978 and 1988 and was implemented in the Arab/Islamic educational tradition. Educational reform needed a new philosophy with accurate goals intended for the present as well as future. The essential issues centered on the citizens: what was the purpose of education and who should be educated? Should education depend on natural interests and abilities? What role should the country play in education, and how should students be educated? The "Law No. 27 of 1988" was passed and started a new philosophy whose principles consisted of beliefs in critical thinking, methodical technique, vocational skills, and developing a positive self-image as well as fine morals, problem-solving, and computer skills necessary to guide the country in the wake of the new century (Massialas \& Jarrar, 1991; Amayreh, 1997). They state:

There should be a rediscovery of the earlier work, which was ahead of its time. In fact, many of these ideas are revolutionary even today. For example, Arab educators observed the differences between the process of education and the individual needs of learners. They believe that education should be a life-long process. (Massialas \& Jarrar, 1991, p. 198)

The general framework of the educational system for the last three decades has been completely autonomous and its philosophy has depended on Arab nationalism and, notably, Islam. Islam has an important role in the development of the society, culture, and the youth. Moreover, Islamic teachings help meet the technological challenges. Islam can "... provide humanity with a rich source of values worthy of leading men to a better life in this world and to salvation in the hereafter" (Nashabi, 1977, p. 28).

According to Al-Sheikh (1999), the Jordanian educational system currently faces a complex set of linked problems. The social and political issues may be linked because they entail democratic principles in order to endure and survive the twenty-first century. He argued that to create a civilized society, people ought to be active participants in the political matters. Nevertheless, the Jordanian people never practiced actual democracy. It was viewed by the educational system as a true challenge because inviting democratic values into Jordanian schools may only be a dream. He adds, "....another challenge for the future school is maintaining the national societal identity as part of Arab identity, which had been formed by the Arab/Islamic civilization" (Al Sheikh, 1999, p. 25). Another researcher writes:

An attempt has been made to offer an interpretive historical growth and development of the Jordanian educational system-what it has been, and what it ought to be. Implicit in this brief historical analysis is the belief that the educational system as it is, and has been, may not survive in the twenty-first century if it is not based on the rich Arab and Islamic heritage. In a sense, the educational system in Jordan can still play a remarkable role in developing or establishing the type of learning institutions equipped to produce the sort of society which honors and cherishes the best of mankind. This may seem a powerful statement, but it is perhaps one of the few cards that Jordanian educators have. By rediscovering the earlier work of the Islamic heritage, which has been scattered through many studies and treaties, the Jordanian educational system, can collect, classify and analyze the earlier educational thought and make it the basis of the new proposed philosophy. (Khasawneh, 2002, p. 55) 
In sum, the new proposed philosophy is one of the major key principles of the Jordanian education system. First, this philosophy includes the Jordanian constitution, the Islamic Arab civilization, the principles of the Great Arab Revolt, and Jordanian national heritage (Al Sheikh, 1999; Amayreh, 1997; Al-Tal, 1998). Second, education must be receptive to current as well as future needs and be able to sustain the country's social and economic growth. Third, a quality education system facilitates global contact with other educational opportunities, fairness in terms of providing services, and provides advantages along with improvement in terms of new information technology. Moreover, a good education system endorses civilized levels of student achievement via a performance indicator system that is based on principles rooted in learning. To conclude, the vision and mission of the Jordanian education system should be incorporated into national policymaking (Amayreh, 1997; Al-Tal, 1998).

To achieve this study's purpose, two research methods were used - quantitative and qualitative - which will be explained in more detail in the Methodology section.

\section{METHODOLOGY}

An effective research narrative should help readers arrive at the same conclusions as the researchers. The researchers' task is to make available the means for making conjectures about the study's findings and results (Tashakkori \& Teddlie, 1998). In this study, the researchers used quantitative and qualitative research techniques. The quantitative component was incorporated to strengthen this study by collecting data from a large number of participants who responded to many questions within a relatively short period. The qualitative approach provides information that emerged from a group of people to describe aspects of the topic under investigation. According to Neuman (2000), the qualitative method helps provide a deep understanding of the phenomenon. Survey questionnaires are valuable as response rates are usually high for a target population who is well educated and has an interest in the research topic.

The quantitative method was useful in this study as the researchers were able to combine a diverse set of information from the study sample and determine relationships between variables. This approach generated extensive information on Jordanian public school teachers who expressed to a moderate degree their belief that pragmatism is implemented in Jordan. Qualitative methods deepen and add value to quantitative studies. Here, this method presented an in-depth analysis of the complexities of the Jordanian public school teachers who articulated their views regarding the influence and implementation of Dewey's philosophical thought throughout Jordanian schools. Berg (1995) argues qualitative methods refer to the what, how, when, and where, therefore providing meanings, concepts, and definitions.

By employing the quantitative method, the researchers were interested in asking several Jordanian educators about the implementation of Pragmatism and the educational thought of John Dewey in the Jordanian public schools as a way to understand their experiences, knowledge, practice, and meanings. The purpose of employing the qualitative method was to gain a subjective understanding of the experiences of the participants and their meanings (Seidman, 1991). Both methodologies were used because even though they differ in many ways, they still complement each other. Therefore, the strengths each approach brings were valued (Neuman, 2000). The qualitative method allows a deeper understanding through examination of what the participants say about their knowledge of the implementation of pragmatic educational thought throughout the Jordanian public schools.

\section{The Participants}

In order to draw conclusions that are relevant to additional groups of people, researchers must decide on a sample representative of its population. In qualitative studies, it is not feasible to develop a statistical analysis that includes a large number of individuals who must provide consent to participate in research studies. These individuals would be engaged in the experience. For this reason, there is always a self-selection factor in these types of studies (Tashakkori \& Teddlie, 1998; Seidman, 1991; Reason, 1994). Thus, one of the researchers selected ten graduate students from his course on philosophical thoughts (schools) and their educational implementations, and asked them to respond to an open question. These master's students were also school teachers who have had more than five years of teaching experience. They were asked to participate towards the end of the semester and upon the completion of the course so that they would have a good understanding of Pragmatism prior to answering the question. 
The other instrument employed in this study consisted of a questionnaire that was distributed among (171) teachers chosen randomly in the northern part of Jordan. Among these participants, 59\% were males and $41 \%$ were females. The teachers' majors were divided into two areas: $59 \%$ specialized in humanities and $41 \%$ specialized in science. Their teaching experience was divided into three groups: $24 \%$ had less than five years, $29 \%$ had between five and ten years, and $47 \%$ had more than ten years.

\section{Instrument}

The researchers constructed an instrument to assess the extent to which Pragmatism is implemented in Jordanian public schools. The instrument consisted of 21 items that addressed John Dewey's ideas on education. For the purposes of measuring the extent to which Dewey's ideas were implemented, the researchers measured the total scores from the 21 items. Respondents rated the 21 items according to whether they agreed with each statement using a 5-point Likert scale ranging from 1 (totally disagree) to 5 (totally agree). The criterion for assessing the degree to which the teachers implemented pragmatism was based on the following scale: 1 to 2.6 was categorized as weak, 2.6 to 3.4 was categorized as moderate, and 3.4 to 5 was categorized as strong.

To determine validity, the questionnaire was reviewed by a panel of five experts who are faculty members within the College of Education at Yarmouk University. Their feedback was taken into account, and changes recommended by the validation panel of experts were incorporated into the study instrument. A quantitative approach was used in this study in order to aid the researchers in analyzing the characteristics of a large number of individuals with multiple issues within a moderately short period. The quantitative component included data from smaller clusters of participants to present certain features as well as data from the larger group. Demographic information, including teachers' specialty areas, teaching experience, and gender of the respondents, was also added to the questionnaire items.

\section{Validity and Reliability Measures}

\section{Content Validity}

Content validity refers to the extent to which the content of the measurement reflects the subject matter about which conclusions are to be made (Isaac \& Michael, 1995). In this study, a panel of experts assisted the researchers in assessing the items included in the instrument. All the experts were university professors of education who are knowledgeable of John Dewey's pragmatic philosophy. All the experts decided that the items reflected this philosophy and John Dewey's ideas on education. In addition, the panel reviewed the items for clarity and preciseness, and insured the validity of the instrument.

\section{Internal Consistency}

The researchers estimated the internal consistency of the instrument using Cronbach's coefficient alpha in order to examine whether the items are correlated with each other and measure the same concept. The internal reliability of the instrument was found to be 0.91 in this study.

\section{RESULTS}

\section{The Presentation of Data Results: Quantitative Analysis}

This section analyzes the data obtained from 171 questionnaires completed by Jordanian public school teachers chosen randomly from the northern part of country. The sample of the study consisted of public school teachers with varying levels of experience, areas of specialization, and genders, which represented the independent study variables. The dependent variable, on the other hand, is the questionnaire of this study, which consisted of 21 statements to which the individuals responded.

This section is divided into two parts. The first part presents the findings of the study that answer the first research question, "To what degree do Jordanian public schools teachers believe that the philosophy of John Dewey is implemented in Jordanian public schools?" 
As shown in Table 1, teachers expressed a moderate degree to all items, except \#15. The researchers infer that this result is related to the fact that Jordanian teachers may deduce that the public schools are not able to implement the pragmatic philosophical views of John Dewey in an appropriate manner. The reason for this is the lack of an appropriate school environment because of a shortage in necessary facilities, which are needed to implement such principles.

Table 1: Mean Scores and Standard Deviation Results of the Degree to Which Jordanian Teachers Believe Pragmatism is Implemented in Jordanian Public Schools

\begin{tabular}{|c|c|c|c|c|}
\hline Item \# & Item & Mean & S.D. & Degree \\
\hline 1 & $\begin{array}{l}\text { The school in Jordan provides its students with ample } \\
\text { opportunities to learn through hands-on activities. }\end{array}$ & 2.7500 & 1.0820 & Moderate \\
\hline 2 & $\begin{array}{l}\text { The teaching methods utilized in Jordanian schools } \\
\text { are based on dialogue, problem-solving, and self- } \\
\text { learning. }\end{array}$ & 2.8118 & 0.9545 & Moderate \\
\hline 3 & $\begin{array}{l}\text { The school provides various opportunities for } \\
\text { students to acquire intellectual and social skills. }\end{array}$ & 2.7917 & 0.9779 & Moderate \\
\hline 4 & $\begin{array}{l}\text { Teaching in Jordan serves realistic goals that benefit } \\
\text { free individuals and democratic society. }\end{array}$ & 2.8994 & 1.0946 & Moderate \\
\hline 5 & $\begin{array}{l}\text { Teaching in Jordan provides students with activities } \\
\text { to practice learning through projects. }\end{array}$ & 2.8049 & 0.9775 & Moderate \\
\hline 6 & $\begin{array}{l}\text { Education in Jordan helps students express their } \\
\text { opinions and make decisions. }\end{array}$ & 2.8049 & 1.0489 & Moderate \\
\hline 7 & $\begin{array}{l}\text { The schools in Jordan refine their students, and help } \\
\text { them become disciplined and good citizens. }\end{array}$ & 2.8383 & 1.1021 & Moderate \\
\hline 8 & $\begin{array}{l}\text { The school is concerned with opening up to the youth } \\
\text { so they could live in a model-environment full of } \\
\text { harmony and solidarity. }\end{array}$ & 3.02202 & 0.9790 & Moderate \\
\hline 9 & $\begin{array}{l}\text { The schools in Jordan provide their students with an } \\
\text { atmosphere that helps create democratic citizens. }\end{array}$ & 2.9882 & 1.1178 & Moderate \\
\hline 10 & $\begin{array}{l}\text { The schools in Jordan are concerned with raising } \\
\text { individuals that continue to contribute to their } \\
\text { communities and take into consideration individual } \\
\text { differences. }\end{array}$ & 3.1294 & 1.0283 & Moderate \\
\hline 11 & $\begin{array}{l}\text { The schools provide each learner with different } \\
\text { opportunities to become an active person who has } \\
\text { certain roles and is not a passive. }\end{array}$ & 3.1765 & 0.9783 & Moderate \\
\hline 12 & $\begin{array}{l}\text { The schools in Jordan are concerned with having the } \\
\text { teacher becoming a guide to students' learning rather } \\
\text { than the source of knowledge. }\end{array}$ & 3.2899 & 1.1445 & Moderate \\
\hline 13 & $\begin{array}{l}\text { The primary goal of the teacher in Jordan is to help } \\
\text { students discover knowledge through experimenting. }\end{array}$ & 3.1152 & 1.0186 & Moderate \\
\hline 14 & $\begin{array}{l}\text { The schools in Jordan view themselves as } \\
\text { laboratories rather than lecture rooms. }\end{array}$ & 2.8133 & 1.0177 & Moderate \\
\hline 15 & $\begin{array}{l}\text { The school's task is to prepare students to } \\
\text { conceptualize social life. }\end{array}$ & 2.4398 & 1.0495 & Weak \\
\hline 16 & $\begin{array}{l}\text { The schools in Jordan help students to not fully } \\
\text { become obedient or to perform imposed duties. }\end{array}$ & 2.9162 & 1.1546 & Moderate \\
\hline 17 & $\begin{array}{l}\text { The schools in Jordan do not neglect the interest or } \\
\text { the needs of the students. }\end{array}$ & 2.7059 & 1.0235 & Moderate \\
\hline 18 & $\begin{array}{l}\text { The schools in Jordan are concerned with guiding the } \\
\text { students' expertise in order to achieve his/her growth. }\end{array}$ & 3.0355 & 0.9874 & Moderate \\
\hline 19 & $\begin{array}{l}\text { The schools in Jordan are concerned with making the } \\
\text { educational process a reflection of the reality outside. }\end{array}$ & 2.9581 & 1.0081 & Moderate \\
\hline 20 & $\begin{array}{l}\text { The schools in Jordan are concerned with making } \\
\text { sure that education addresses realistic needs and does } \\
\text { not indulge in the past. }\end{array}$ & 2.8935 & 1.0238 & Moderate \\
\hline 21 & $\begin{array}{l}\text { The schools in Jordan serve the learner's present } \\
\text { more than his future. }\end{array}$ & 2.8941 & 1.0935 & Moderate \\
\hline
\end{tabular}


In addition to not having appropriate school environments in mainstream Jordanian public schools, many teachers still focus on rote knowledge and strict teaching instead of the "learning by doing" method that Dewey promoted. Therefore, students are not free to voice their opinions or participate in the learning process either inside or outside the classrooms. They must rely on their teachers to do so.

Furthermore, the results in Table 1 show that item \#12, which states "The schools in Jordan are concerned with having the teacher become a guide to students' learning rather than the source of knowledge" had the highest mean score of 3.2899 with a standard deviation of 1.1445 . The researchers believe this result is related to the fact that Jordanian modern curricula give students better opportunities to contribute to the learning process and reduce the teacher's role as the only knowledge transmitter or source.

In addition, item \#15, which states "The school's task is to prepare students to conceptualize social life" had the lowest mean score of 2.4398 with a standard deviation of 1.0495 . The researchers assume that this result is related to the fact that Jordanian teachers still do not believe that a major function of the school is to prepare students for social life in terms of stimulating their social roles within the schools. Some teachers view schools as learning or academic institutions while ignoring the modern perspective that views these institutions as communities in which every member is a learner. Additionally, many teachers do not regard schools as part of the local community. According to them, it is the family's task to shape their children's upbringing in a social context. To answer the first research question, Table 1 shows the mean scores and standard deviation results of the degree to which Jordanian teachers expressed that pragmatism was implemented in Jordanian public schools.

To answer the second research question, Table 2 shows the mean scores and the standard deviation results for the variable of gender. The second research question is the following: Is there any significant statistical difference $(\alpha=0.05)$ between teachers' responses according to their gender, major, and teaching experience.

Table 2: Independent Sample t-Test

\begin{tabular}{|l|c|c|c|c|c|}
\hline \multicolumn{1}{|c|}{ Gender } & $\mathbf{N}$ & Mean & $\mathbf{t}$ & df & P \\
\hline Male & 101 & 2.93 & -0.63 & 160 & 0.6 \\
\hline Female & 61 & 3.00 & -0.647 & 131.635 & \\
\hline
\end{tabular}

$\alpha=0.05$ (nine teachers did not indicate their gender)

Table 2 indicates that there was no statistically significant difference between males and females in terms of their perspective on pragmatism. Table 3 indicates that there was no statistically significant difference between teachers' academic backgrounds (i.e., science or humanities). The results indicated no statistically significant difference according to teachers' background in terms of their views on the implementations of Dewey's ideas in Jordan.

Table 3: Independent Sample t-Test

\begin{tabular}{|l|c|c|c|c|c|}
\hline \multicolumn{1}{|c|}{ Specialty } & N & Mean & t & df & P \\
\hline Humanities & 98 & 2.96 & 0.490 & 163 & \\
\hline Science & 67 & 2.91 & 0.509 & 158.01 & 0.612 \\
\hline
\end{tabular}

$\alpha=0.05$ (Six teachers did not indicate their gender)

Table 4 indicates that there is no statistical difference between teachers' teaching experience in terms of their views on the implementation of John Dewey. A one-way ANOVA was used to test for differences among Jordanian teachers in terms of their teaching experiences. The results indicate no significant difference across the three teaching experience levels, $F(2,166)=0.189, P=0.828$.

Table 4: Analysis of Variance

\begin{tabular}{|l|c|c|c|c|}
\hline \multicolumn{1}{|c|}{ Variable } & Sum Of Squares & DF & F & P \\
\hline Between & 0.193 & 2 & 0.189 & 0.828 \\
\hline Within & 89.755 & 166 & & \\
\hline
\end{tabular}

$\alpha=0.05$ 


\section{The Presentation of Data Results: Qualitative Analysis}

This section presents the qualitative results of the current research. These results are presented in the following manner. First, a thematic discussion of the findings and results, in terms of the research questions, is presented. In particular, the themes that emerged from questioning the 10 participants are described. These findings are presented as the result of the data collected from 10 individuals for the purpose of this study.

In response to the study question, the first respondent articulated that the influence and implementation of Dewey's philosophical thought throughout the Jordanian schools is shameful and disgraceful. As a teacher, she wished the local community would contribute to school curricula, or at least that family members' opinions would be taken into account so that the learning process would be easier on students. She believed that in order to keep up with the advanced changing technological world, Dewey's pragmatic thought should be taken into account and implemented within the Jordanian educational system because of its flexibility. She added, "Change is a necessity. I do not mean that we should revoke or retract the Islamic educational thought though."

The second respondent stated, "In my opinion, the influence and implementation of Dewey's philosophical thought throughout the Jordanian schools is deplorable and a pity." She said this because in Jordan teachers still deliberately provide students with information for memorization, which is implementing idealism in philosophical educational thought. Throughout the Jordanian universities, however, Dewey's philosophy on education is put into practice. The third respondent stated, "The realization and practice of Dewey's philosophical thought throughout Jordanian schools is disgraceful and meager as Islamic education dominates and governs Jordanian school culture." The fourth respondent replied to the study question by stating:

I believe that Dewey's pragmatic thought is clearly demonstrated in the Jordanian educational system by the inclusion of students in the learning process, and by letting students play vital roles and perform different activities and events. The teacher role, however, would be limited to supervise, administer, direct, and oversee.

The fifth respondent argued that in Jordan, the teaching/learning process is definitely not pragmatic, but in some cases, it is well thought out, especially in cases where the experimental approach is employed involving problem-solving and scientific methods. Evaluating students depends a great deal on memorization because we do not experience practical or utilitarian things progressively. She added, "Islamic education leads and rules Jordanian school traditions." The sixth respondent inferred that Dewey's philosophical thought has undoubtedly been influential, well known, and prominent not only throughout the Jordanian schools but regionally and worldwide as well. Throughout our schools, Dewey's philosophical thought has been promoted from a practical perspective; that is, the traditional curricula that centers on subject matters only have been abandoned. The modern curricula consist of a variety of activities such as games, field trips, and library visits. The seventh respondent stated:

Traditionally speaking, the teacher has been the center or the heart of the teaching process in addition to the subject matters. This is no longer the case. The center of the teaching process has now shifted, as a result of the influence of pragmatic thought, to the student. That is, while students responsively participate, discuss, and get involved in dialogue with peers as well as with the teacher, teachers assist, facilitate, direct, and supervise the teaching process. However, when it comes to research, pragmatic thought has not yet reached the Arab world at the same level that has been reached by the Western world.

The eighth respondent felt that Dewey's philosophical thought depends to a great extent on the learner and stated, "I think that his educational philosophy is not implemented in Jordan since the traditional style prevails and is still dominant. Islamic education dominates Jordanian school traditions." Pragmatic thought is practical and utilitarian, and its followers believe in continuous change. The ninth respondent alleged that the implementation of Dewey's philosophical thought, which calls for subject matters to be integrated, is disgraceful. Learning relies on memorization in Jordan. On some occasions, however, and because of its flexibility, some Jordanian teachers employ pragmatic thought. Finally, the tenth respondent summarized her input by stating:

Dewey's philosophical thought is sometimes implemented throughout the Jordanian schools when academic activities are held in laboratories. In addition, problem-solving is applied in classrooms. I think the pragmatic 
thought of John Dewey is not implemented throughout the Jordanian schools because Pragmatism involves experiments, research, and the scientific method. In Jordan, education is based more on theory rather than practice.

In summary, several reasons account for why the study participants responded to the study question in the ways that they did. First, some participants did not yet comprehend the pragmatic philosophical thought in a way that would help them put it into practice. Second, there are differences among schools in Jordan; that is, some of them implement this philosophy while others still employ the traditional philosophy. Further analysis of this difference will be addressed in the discussion section of this paper.

In general, the qualitative data is consistent with the results of the quantitative analysis. That is, Dewey's thought is implemented only partially in Jordanian public schools. Some teachers expressed that their views are implemented to some extent; however, most of them expressed that more effort is needed and that a shift from traditional teaching to progressive teaching methods should be executed. For example, teachers would like to see a shift from rote memorization to experimentation, and a shift from the passive role of the learner to an active one where the learner is exploring, experimenting, justifying, and expressing his/her views openly and freely. In addition, a shift from the dominant role of the teacher to one that facilitates students' learning should be realized.

One interesting observation is that only a few school teachers in this study expressed that Dewey's thoughts are not implemented because Islamic educational thoughts rule the school system. The authors value the participants' views as they do not believe that Dewey fully contradicts Islamic educational thoughts. In fact, pioneering scientists such as Ibn Roshd, Ibn Siena, and Al-Kwarizme have implemented Islamic thoughts that are parallel with Dewey's school of thought. Further elaboration on this point will be presented in the discussion section of this paper.

In general, teaching methods throughout Jordanian public schools focus mostly on lecturing as well as recitation or presentations provided by teachers. Dialogue and discussions rarely take place inside the classrooms so that students are able to ascertain and elucidate facts (The official web site of the Ministry of Education in Jordan). For Pragmatists, however, teaching methods focus on hands-on problem-solving, experimenting, and projects, often having students work in groups. Unfortunately, this is not the case in Jordan. For example, collaboration is an effective teaching method that permits students to contribute to the learning process and work together in a joint intellectual effort through listening to other points of view and communicating with each other. Furthermore, collaboration encourages a personal association between students and the study subject, which helps them to reflect on their studies in a less prejudiced way. Small group discussions, group projects, teamwork, and cooperation are examples of collaboration that teachers may utilize to evaluate students' abilities to develop leadership as well as presentation skills (Walther-Thomas, Korinek, McLaughlin, \& Williams, 2000).

\section{DISCUSSION AND CONCLUSION}

Dewey's educational pragmatic thoughts affected schooling by encouraging more student- rather than curriculum-centered schools. As an alternative to teaching and transmitting information to learners, students are taught to be graceful and organized in order to familiarize themselves with ever-changing environments. Learners are concerned more about the achievement of the group rather than the accomplishment of individuals. His pragmatist ideas influenced education by encouraging more students instead of curriculum-centered schools. Instead of teaching facts, students are taught to be flexible and adaptive to ever-changing conditions. Students are also encouraged to worry more about the success of the group rather than the success of the individual. State standards in public education have reduced the influence of pragmatism in school since students are now expected to master specific material.

The student-centered curriculum calls for team teaching and courses offered by different departments. Projects and hands-on experiences have definite advantages over lectures. According to pragmatists, this methodology focuses on giving students a great deal of autonomy as well as alternatives to their current learning circumstances. The learning environment turns into a methodical laboratory in which thoughts are experienced to determine whether they can be authenticated. 
The problems chosen for explaining have to be genuine and true issues for the student. The problemsolving technique is embedded in the mental/emotional state and the desires of the learner instead of the traditional array of subject matters. This technique helps children utilize their aptitude in addition to learning methodical methods of solving problems that are relevant to their lives. Learners embrace these healthy opportunities to involve themselves in first-hand interactions with the environment and field trips are more effective than, for example, reading or audio-visual practice. In other words, a pragmatic curriculum is concerned with transforming theory into practice.

The researchers believe that more should be done in Jordan to enlighten Jordanian teachers about this influential figure. Given that the entire Middle East region is moving towards more democratic societies, especially in the context of the Arab Spring, it is important to note that democratic societies require democratic individuals. John Dewey's ideas provide students with an atmosphere that helps create a democratic citizen. The current study reveals that Jordanian teachers expressed their belief that Pragmatism is implemented to a moderate degree in Jordan. Therefore, more effort should be made to advocate this philosophy.

The whole education community, including teachers, administrators, curriculum developers, and decision makers, should be involved and concerned with advocating for more democratic, independent, and creative thinkers. It is the researchers' belief that education is not about getting information into the minds of students; rather, children cannot learn unless they are active, using their hands and engaging in varied sorts of experimentation. Teachers also should be physically active in order to teach. They will not teach effectively if they think of themselves as information machines passing on data from one mind to the next. Dewey is a productive and constructive philosopher who tried to do justice to a belief that stressed the continuity between nature and culture. Now, more than ever, John Dewey's pragmatic ideas are relevant and needed in Middle Eastern countries, especially those classified as Third World, in order for those societies to strive in the modern world. Dewey's philosophy has influenced not only education but also psychology, jurisdiction, literature, and politics.

Curriculum should bring together disciplines and concentrate on solving problems in an interdisciplinary manner instead of passing down planned knowledge to learners. Pragmatists believe that learners should put into practice knowledge in actual conditions through experimental investigation. This approach trains learners for citizenship and future professions. These skills are something students throughout Jordanian schools will need since they may not otherwise know the true meaning of citizenship or how to become good citizens. They believe citizenship is a status quo. Pragmatism could help prepare them for citizenship since Jordan is going through many changes. Students need to learn to work together in groups in the classroom and in their community to help them grow and become good citizens and, in the future, effective citizens.

Pragmatism has the power to transform educational thought in Jordan. It can identify a clear need in educational thought in light of the latest transformations in the economic, political, and social climates in Jordan. It is now more vital that such an approach be developed. Pragmatism could aid and support Jordanian students from various backgrounds and environments to work courteously with each other and contribute to a new social order. According to pragmatic educational theory, learners should be aware of the consequences of their assessments and how the entire group is influenced.

For Pragmatists, teaching methods focus on hands-on problem-solving, experiments, and projects, often having students work in groups. Unfortunately, this is not the case in Jordan. In Jordan, teaching methods focus on the mastery of facts and basic skills through demonstration and recitation. Teaching methods also focus on disseminating ideas through lecture and discussion and by using questioning to help students discover and clarify knowledge.

Traditional Islamic philosophy involves a balance between individualism and collectivism. The improvement of the individual is an essential value, but this does not discount the development of social wisdom and cooperative tasks. People are supposed to maintain their individualities in a collective and social way. Thus, an ideal educational system will always aim to establish a balance between the growth of uniqueness and the social awareness of the individual. Hence, the main function of education should be to imbue students with this creed and philosophy. They should be educated and well informed about the goal and meaning of life. Education has to 
generate individuals with deeply held beliefs regarding the Islamic standards of personhood along with notions of a collective life.

During the nineteenth century, a gap existed between the West and the Islamic world. A diverse set of clarifications for this gap has been offered. The modern world makes it necessary for groups of diverse beliefs and traditions to communicate. Islam should coexist with the contemporary Western world; however, this does not entail yielding to all Western cultural practices. Moreover, several Muslim thinkers adapted Western philosophy in order to comprehend the philosophical dilemma in which they are interested. For example, Zaki Najib Mahmud pursued William James in presenting a pragmatic enlightenment of philosophy. Some of them compared particular practices in Islamic institutions to philosophy (Leaman \& Morewedge, 1998).

With the revival and renewal of Islam in some Muslim societies, Islamization, a newly introduced terminology, emerged recently as a reaction to modernity. Some Muslim countries hope to embrace each type of knowledge with conventional Islamic standards and control the secularization and transformation as well as reconstruction of knowledge. This motivation is the result of a major political encounter to institute a new political discourse connecting state and religion. This is embedded in the Muslim culture in which virtuous discourses arbitrate political authority along with public control (Geertz, 1971).

Islamization is an effort to make Islam a foundation of power and global social control by incorporating structures of rituals and values. Such an effort would help people view Islam as an inclusive way of life rather than simply a religion. In a number of Muslim countries, this has been a primarily sociopolitical and economic battle, although it arises fundamentally from the acceptance of conventional knowledge as a priori understanding. In this context, education plays an essential role in recreating Muslim culture and endorsing the ideological aspirations of the revitalization of Islam. The transformation of community dialogue required by this renaissance could give rise to adjustments in power structure and social control, which are legally recognized in addition to standardized knowledge among the general public (Geertz, 1971).

In terms of the Jordanian educational system, the Ministry of Education initiated a 10-year education reform plan to advance the quality and significance of education in 1988. The purpose was to reorganize the national school curriculum in order to focus on increasing students' problem-solving and critical thinking skills, in addition to their ability to link academic knowledge to real life situations. A second reform plan was launched by the Ministry during the period of 1998-2002, aimed at upgrading and promoting teachers' skills, school administration, educational information systems, preschool education, and education for children with special needs. This plan aimed at an inclusive transformation (The official web site of the Ministry of Education in Jordan).

Furthermore, the researchers believe that conducting this study in Jordan is important because the country is experiencing dramatic political and economic changes. Pragmatic ideas could be implemented to help build democratic citizens. Pragmatic educational practices that take the learner's views into account generate independent individuals who eventually become free thinkers. Listening and respecting others may help produce democratic citizens. In other words, tolerance is the result of a democratic generation of young people who are able to think freely. To conclude, the researchers will introduce some similarities as well as differences between Islamic and pragmatic principles.

Both Islamic and pragmatic teachings view the human being as a social entity who searches for freedom, and that education is a social phenomenon. Ethics are acquired through direct experience in addition to practice. Correspondingly, learning occurs through doing as well as interacting with one's environment. Therefore, both teachings are concerned with the individual and democracy. The major differences, on the other hand, suggest that in Pragmatism, the welfare of the individual comes before the welfare of the society; however, in Islamic teaching, these concepts are treated equally. Second, Pragmatism views ethics as humanist since morality and truth are found through the process of investigation; however, in Islam, Shareaa (the Quran and Prophetic traditions) determines the basis and meaning of morality. Another difference is that in Pragmatism, the concern of education is improving one's life; in Islamic teaching, the goal is to improve one's life and beyond. The objectives of education in Pragmatism are concerned with the development of a social, intellectual, physical, and emotional individual, but Islamic teaching adds to that spirituality and a successful relationship with God. 
Literature includes several works that provide evidence of a relationship between Islamic traditional and pragmatic educational thought. For example, many Muslim thinkers identified some contradictions between these schools of thought, while others proved the opposite. However, the holy book, as well as the Prophetic tradition that knowledge must be searched for by all Muslim men and women, state that there is no violation of the oneness of God.

\section{AUTHOR INFORMATION}

Omar Khasawneh, who received his Ph.D. in Education from the Ohio State University in 2002, is an associate professor of Education at Al Ain University of Science and Technology on a Sabbatical Leave from Yarmouk University in Jordan. He taught at the Department of Educational Foundations at the UAE University throughout the period of February 2004 and August 2007. At the higher education level, he has been teaching graduate in addition to undergraduate courses. He published a number of research papers, presented several papers and conducted numerous workshops in different areas related to his academic and research interests at local, regional and international journals as well as conferences. For the last four years, he has been supervising MA and Ph.D. students, refereeing research papers and articles corresponding to his research interests. He also had been involved in the College of Education (NCATE) Accreditation Process and received a Merit Increase \& Recognition from the Associate Provost for Academic Affairs in 2006 while being a faculty member at UAE University. Moreover, he has been engaged in numerous professional associations and involvement as he delivered community as well as institutional services. E-mail: khasawneh.6@juno.com (Corresponding author)

Dr. Ruba Miqdadi is an Assistant Professor of mathematics education in the Department of Curriculum \& Instruction at Yarmouk University in Jordan. She earned her bachelor in Computer Science from Yarmouk University. Ruba traveled to the United States of America where she earned her Master's Degree in Mathematics Education at Northern Illinois University and Doctoral degree in Mathematics Education at Southern Illinois University. She then worked as an Assistant Professor at Dubai University in United Arabs Emirates for one year. Ruba traveled back to the States and taught courses in pure mathematics and mathematics education at Southern Illinois University.

Dr. Abdel-Hakeem Hijazi is an Associate Professor in the Department of Educational Administration and Educational Foundation at Yarmouk University. He earned his bachelor in history in Yarmouk University. Then he earned his Master's and Doctoral degree from Kazam University in Russia. He worked at University of Mu'ta and University of Al-Hussain. He is interested in conducting research in philosophical and educational foundation.

\section{REFERENCES}

1. $\quad$ Alexander, T. (1987). John Dewey's theory of art, experience, and nature. SUNY Press.

2. Al Sheikh, O. (1999). The Jordanian school and the twenty-first century's challenges: The introduction. Amman, Jordan: Abdel hameed Shoman Institute Publications.

3. Al-Tal, A. Y. (1998). Higher education/learning in Jordan. Amman, Jordan: Committee of Jordan's History Publications.

4. Amayreh, M. H. (1997). Education and learning in Jordan: From Ottoman Era to 1997. Amman, Jordan: Al-Massereh Publication Company.

5. Berding, J. W. A. (1999). John Dewey's participatory philosophy of education, experience and curriculum: A summary. Leiden: Amsterdam, Netherlands: DSWO Press.

6. Berg, B. L. (1995). Qualitative research methods for the social sciences. Boston: Allyn and Bacon.

7. Boisvert, R. D. (1988). John Dewey: Rethinking our time. Albany: State University of New York Press.

8. Brewer, J., \& Hunter, A. (1989). Multimethod research: A synthesis of styles. Newbury Park, CA: Sage Publications.

9. Bullert, G. (1983). The politics of John Dewey. Buffalo, NY: Prometheus Books.

10. Campbell, J. (1995). Understanding John Dewey: Nature and cooperative intelligence. Chicago: OpenCourt.

11. Damico, Alfonso J. (1978). Individuality and community: The social and political thought of John Dewey. Gainesville, FL: University Presses of Florida. 
12. Darling-Hammond, L., \& Sclan, E. (1996). Who teaches and why: Dilemmas of building a profession for twenty-first century schools. In J. Sikula, T. J. Buttery, \& E. Guyton (Eds.), Handbook of Research on Teacher Education (2nd ed.). New York: Macmillan.

13. Dewey, J. (1944). Democracy and education. New York: the Free Press.

14. Dykhuizen, G. (1973). The life and mind of John Dewey. Carbondale: Southern Illinois University Press.

15. Eames, S. M. (2003). Experience and value: Essays on John Dewey and pragmatic naturalism. Elizabeth R. Eames and Richard W. Field, Eds. Carbondale: Southern Illinois University Press.

16. Eldridge, M. (1998). Transforming experience: John Dewey's cultural instrumentalism. Nashville: Vanderbilt University Press.

17. Field, R. (2007). John Dewey (1859-1952). The internet encyclopedia of philosophy. Maryville, Northwest Missouri State University.

18. Geertz, C J. (1971). Islam observed, religious development in Morocco and Indonesia. University of Chicago. Chicago Press.

19. Hickman, L. (1990). John Dewey's pragmatic technology. Bloomington: Indiana University Press.

20. Hickman, L. A., (1998). Ed. Reading Dewey: Interpretations for a postmodern generation. Bloomington and Indianapolis: Indiana University Press.

21. Hook, Sidney. (1995). John Dewey: An intellectual portrait. New York: John Day Co. 1939; New York: Prometheus Books.

22. Isaac, S., \& Michael, W. (1995). Handbook in research and evaluation. San Diego, CA: Educational and Industrial Testing Services.

23. Johnson, T. W. (1995) Discipleship or pilgrimage? State University of New York Press.

24. Jordanian Society for Inheritance Care. (1997). Amman, Jordan.

25. Kaminsky, J. S. (1992). A pre-history of educational philosophy in the United States: 1861 to 1914 , Harvard Educational Review, 62, 181.

26. Khalifeh, S. M. (1986). The history of organized sports in Jordan. (Ph.D. Dissertation). University of Miami, Coral Gables, Florida.

27. Khasawneh. O. (2002). Looking at the present, looking towards the future: Sport and physical education in Jordan. (Ph.D. Dissertation). Ohio State University, Columbus, Ohio.

28. Leaman, O., \& Morewedge, P. (1998). Modern islamic philosophy. In: Craig, Edward (Hrsg.). Routledge Encyclopedia of Philosophy. London.

29. Massialas, B. G., \& Jarrar, S. A. (1991). Arab education in transition: A source book. New York and London: Garland Publishing, INC.

30. Ministry of Education Jordan. http://www.moe.gov.jo/

31. Nashabi, H. (1977). Islam and the liberal tradition. In: The liberal arts and the future of higher education in the Middle East. Beirut, Lebanon: American University of Beirut.

32. Neuman, W. L. (2000). Social research methods: Quantitative and qualitative approaches. Boston: Allyn and Bacon.

33. Patton, M. (1990). Qualitative evaluation and research methods. Newbury Park: Sage Publication.

34. Randall, R. (1968). Jordan and the Holy Land. London: Fredrick Muller.

35. Ryan, A. (1995). John Dewey and the high tide of American liberalism. New York: London.

36. Reason P. (1994). Three approaches to participative inquiry. New York: Thousand Oaks, Sage Publications.

37. Rockefeller, S. C. (1991). John Dewey: Religious faith and democratic humanist. New York: Columbia University Press.

38. Rorty, R. (1979). Philosophy and the mirror of nature. Princeton: Princeton University Press.

39. Schilpp, P. A., \& Lewis, E. (1989). The philosophy of John Dewey. The Library of Living Philosophers: Open Court Publishing Company.

40. Seale, P. (1983). The shaping of an Arab statesman. London: Quartet Books Limited.

41. Seidman, I. E. (1991). Interviewing as qualitative research: A Guide for researchers in education and social sciences. New York: Teachers College Press.

42. Sleeper, R. (1987). The necessity of pragmatism: John Dewey's conception of philosophy. New York: Yale University Press.

43. Soraty, I. Y. (2008). The impact of pragmatism on Arab education: Its aspects, sources, and consequences. Journal of Dirasat, University of Jordan, 35, 590-603. 
44. Tashakkori, A., \& Teddlie, C. (1998). Mixed methodology: Combining qualitative and quantitative approaches. London: Thousand Oaks, Sage Publications.

45. Thayer, H. S. (1952). The logic of pragmatism: An examination of John Dewey's logic. New York: Humanities Press.

46. Tiles, J. E. (1988). Dewey. London: Routledge.

47. Walther-Thomas, C., Korinek, L., McLaughlin, V. L., \& Williams, B. (2000). Collaboration for inclusive education: Developing successful programs. Needham Heights, MA: Allyn and Bacon.

48. Welchman, J. (1995). Dewey's ethical thought. Ithaca: Cornell University Press.

49. White, M. (1943). The origin of Dewey's instrumentalism. Columbia University Press. 